JESTT Vol. 1 No. 7 Juli 2014

\title{
PENGARUH BAURAN PEMASARAN TERHADAP NIAT MENJADI MITRA PERSPEKTIF ISLAM PADA BMT BERINGHARJO CABANG MADIUN
}

\author{
Mega Ayuning Tyas \\ Mahasiwa Program Studi S1 Ekonomi Islam - Fakultas Ekonomi dan Bisnis - Universitas \\ Airlangga \\ Email: mega22ayu@gmail.com \\ Ari Prasetyo \\ Departemen Ekonomi Syariah - Fakultas Ekonomi dan Bisnis - Universitas Airlangga \\ Email: ari_feunair@yahoo.co.id
}

\begin{abstract}
:
This study aims to analyze The Effect of Marketing Mix Towards Intention become Partner on Perspective of Islam at The Branch Office of BMT Beringharjo in Madiun. The tests carried out using multiple linear regression method, where the endogenous variable $(Y)$ is a intention become partners and exogenous variables $(X)$ is the marketing mix that is identified with product (X1), price (X2), place/distribution channel (X3), promotion (X4), people (X5), process (X6), physical evidence (X7), promise (X8), and patience (X9). In this study added two variables in the marketing mix of services in accordance with Islamic values that promise and patience.

This study uses a quantitative approach. The characteristics of the population inthis studi is a partner at The Branch Office of BMT Beringharjo in Madiun are actively engaged in transactions in 2014 and live in Madiun. Total sample of the respondents is 100 (one hundred). These samples were selected using nonprobability sampling with purposive sampling method with particular consideration .

The results of this study indicate that simultaneous and partially, marketing mix variables consisting of product, price, place/distribution channel, promotion, people, process, physical evidence, promise, and patience shown the effect to intention become a partner on perspective of Islam at the branch office of BMT Beringharjo in Madiun. Variable place/distribution channel is the most dominant variable to the intention become partners on perspective of Islam at the branch office of BMT Beringharjo in Madiun.

Suggestion for the branch office of BMT Beringharjo in Madiun should increase promotional activity to be more diverse so it can attract attention to prospective partners or partners who have joined, socialize product from BMT Beringharjo more clearly and detail, especially the difference with the product from conventional bank, and make a direct sales pitch way more exciting and creative by adding facilities and infrastructure in the promotion or by making a series of interesting activities and carried out in the crowd with direct sales activities.
\end{abstract}

Keywords : product, price, place/distribution channel, promotion, people, process, physical evidence, promise, patience, and intention become partners on perspective of

Islam.

\section{PENDAHULUAN}

Aktivitas

perekonomian

di

Indonesia mulai kembali bangkit

beberapa tahun belakangan ini dengan

hadirnya sistem ekonomi yang baru yaitu ekonomi Islam dimana segala aktivitas perekonomian didasarkan pada nilai-nilai Islam. Berdasarkan data, pertumbuhan aset industri keuangan ekonomi Islam pada tahun 2012 mencapai 34 persen. 
Pertumbuhan ini melebihi pertumbuhan industri keuangan konvensional yang mencapai 15 sampai 20 persen (bisniskeuangan.compas.com, 20 Juni 2014, 19:51). Pertumbuhan itu ditunjang dengan bermunculannya lembaga kevangan syariah di Indonesia baik bank maupun non-bank yang terdiri dari Perbankan syariah, Asuransi Syariah, Pegadaian syariah, BMT (Baitul Maal Wat Tamwil) dan masih ada beberapa lagi lainnya.

BMT (Baitul Maal Wat Tamwil) salah satu lembaga keuangan yang perkembangannya terlihat signifikan. Berdasarkan data yang dimiliki oleh Kementerian Koperasi dan Usaha Mikro, Kecil dan Menengah, sampai akhir tahun 2011, unit koperasi secara umum berjumlah 187,598 unit dimana 71,365 unit diantaranya merupakan unit koperasi simpan pinjam, dan kurang lebih 5,500 unit diantaranya adalah BMT (http://www.setkab.go.id, 14 Maret 2014, 21:11). Sesuai dengan prinsip koperasi yang diterapkan dalam kinerja operasional, BMT memiliki fungsi untuk membangun dan mengembangkan potensi dan ekonomi anggota khususnya masyarakat pada umumnya dan juga mensejahterakan masyarakat kalangan bawah agar dapat meningkatkan taraf hidup dan kualitas hidup merka serta membantu dalam upaya pemerataan distribusi kekayaan agar tidak berputar di kalangan orang berada saja.

Semakin menjamurnya lembaga keuangan Islam di Indonesia, menjadi tantangan bagi masing-masing lembaga keuangan Islam untuk memiliki strategi pemasaran yang efektif agar mereka tetap bisa bertahan. Menurut Arief (2005:59) perusahaan harus memilih strategi yang tepat dalam rangka menggaet konsumen dengan mengkombinasikan berbagai marketing tools baik dari segi produk, harga, distribusi dan promosi. Keempat elemen tersebut yang sering dinamakan marketing mix.

Bauran pemasaran (marketing mix) menurut Sumarni (2003:274) adalah kombinasi dari variabel atau kegiatan yang merupakan inti dari sistem pemasaran yaitu produk, harga, kegiatan promosi dan sistem distribusi. Menariknya dalam penelitian ini menggunakan bauran pemasaran perspektif Islam yang ditambahkan 2 variabel yang murni islami yaitu janji dan kesabaran yang merupakan hasil pemikiran dari Samir Abuznaid (2012).

Dalam penelitiaan ini obyek penelitian BMT Beringharjo Cabang Madiun. BMT Beringharjo ini cukup menarik minat masyarakat, terbukti BMT Beringharjo sudah memiliki beberapa cabang di pulau Jawa diantaranya ialah Madiun, Ponorogo, Caruban, Nganjuk, Kediri, Ngawi, Pabringan, Yogyakarta, Semarang, Bandung dan Bintaro. Dari hasil pre-research yang dilakukan sebagian besar masyarakat yang menjadi mitra BMT Beringharjo ini dikarenakan nisbah yang ditawarkan BMT Beringharjo cukup besar, produk-produk yang ditawarkan cukup beragam, pelayanan yang memuaskan, 
menerapkan sistem personal selling, kondisi yang terkesan akrab, lokasi yang strategis, disertai fasilitas penunjang lainya. Beberapa alasan yang dikemukakan mitra BMT Beringharjo tersebut mengarah pada faktor bauran pemasaran. Hal ini menggambarkan bahwa bauran pemasaran memiliki pengaruh terhadap niat masyarakat menjadi mitra BMT Beringharjo.

Adapun pokok permasalahan dalam penelitian ini adalah apakah bauran pemasaran jasa yang terdiri dari produk, harga, promosi, tempat, orang, proses, bukti fisik, janji, dan kesabaran memiliki pengaruh yang signifikan secara simultan dan parsial terhadap niat menjadi mitra perspektif Islam pada BMT Beringharjo cabang Madiun. Selain itu juga untuk melihat variabel mana yang paling dominan dari 9 variabel bauran pemasaran yang digunakan. Penelitian ini bertujuan untuk mengetahui pengaruh bauran pemasaran yang meliputi produk, harga, promosi, tempat, orang, proses, bukti fisik, janji dan kesabaran terhadap niat menjadi mitra perspektif Islam pada BMT Beringharjo cabang Madiun.

\section{LANDASAN TEORI}

\section{Pemasaran Islam}

Pemasaran menurut Kotler dan Amstrong (2001:7) memiliki definisi suatu proses sosial dan manajerial yang membuat individu dan kelompok memperolah apa yang mereka butuhkan dan inginkan lewat penciptaan dan pertukaran timbal balik produk dan nilai dengan orang lain. Dalam segi pandang Islam pemasaran menurut Kartajaya dan Muhammad (2006:26) memberikan definisi lain tentang pemasaran Islam yaitu sebuah disiplin bisnis strategi yang mengarahkan proses penciptaan, penawaran, dan perubahan value dari suatu inisiator kepada stakeholders-nya, yang dalam keseluruhan prosesnya sesuai dengan akad dan prinsip-prinsip muamalah (bisnis) dalam Islam.

Tidak bebrbeda dengan pemahaman berkaitan dengan proses pemasaran Islam dijalankan, etika marketer Islam juga sangat berbeda. Dalam pemasaran Islam para pemasar hendaknya menjadikan Rasulullah SAW sebagai tauladan dalam berperilaku dan menjalankan aktivitas pemaaran, hal ini tercantum dalam Al-Quran surat Al-Ahzab ayat 21 (Departemen Agama Rl:2005) :

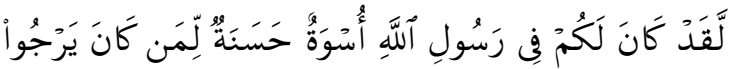

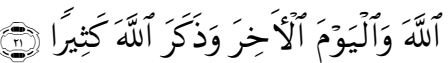

La-qad kāna lakum fị rasūli llahi 'uswatun hasanatun li-man kāna yarjū Ilāhi wa-lyawna I-'ākhira wa-dhakara llāhi kathïa(n).

Artinya: Sesungguhnya telah ada pada (diri) Rasulullah itu suri teladan yang baik bagimu (yaitu) bagi orang yang mengharap (rahmat) Allah dan (kedatangan) hari kiamat dan Dia banyak menyebut Allah.

\section{Bauran Pemasaran Islam}

Perusahaan demi mencapai tingkat pemasaran yang kuat diperlukan 
sebuah strategi pemasaran. Strategi bisa menjadi salah satu pembeda antara perusahaan yang satu dengan yang lainnya. Karena dari strategi tersebut bisa menggambarkan kelebihan ataupun kekurangan dari perusahaan tersebut. Strategi pemasaran yang efektif tersebut salah satunya ialah dengan mengkombinasikan elemen-elemen dari bauran pemasaran. Menurut Lupiyoadi (2009:70) bauran pemasaran (Marketing Mix) merupakan alat bagi pemasar yang terdiri atas berbagai unsur suatu program pemasaran yang perlu dipertimbangkan agar implementasi strategi pemasaran dan positioning yang ditetapkan dapat berjalan sukses. Bauran pemasaran jasa menurut perspektif Islam secara umum sama dengan bauran pemasaran jasa pada konventional yaitu terdiri dari produk, harga, tempat/saluran distribusi, promosi, sumber daya insani, proses, dan bukti fisik. Sedangkan yang membedakan ialah adanya penambahan 2 variabel baru yang murni sesuai nilai Islam berdasarkan teori yang dikemukakakn oleh Abuznaid (2012) yaitu janji dan kesabaran.

Produk

Produk menurut Kotler dan Amstrong (2001:11) adalah segala sesuatu yang dapat ditawarkan kepada pasar untuk diperhatikan, dimiliki, digunakan, atau dikonsumsi yang dapat memuaskan keinginan atau kebutuhan. Produk dalam Islam memiliki pengertian hampir sama yang membedakan ialah produk hanya sebagai pemenuh kebutuhan bukan pemuas keinginan. Selain itu produk dalam Islam harus memenuhi kriteria pertama dilarang mengandung praktek kecurangan, maysir, dan riba (Abuznaid,2012). Hal ini dapat diartikan bahwa produk harus sesuai dengan prinsip-prinsip syariah islam yaitu halal dan tidak mengandung hal-hal yang dilarang dalam al-Quran dan Hadits. Kedua, produk dalam etika bisnis Islam juga mengharuskan informasi yang akurat diberikan tidak hanya kepada barang yang dijual tetapi juga dalam hal periklanannya (Abuznaid:2012). Ketiga, Nafik (2009:110) berpendapat karena Islam mengharamkan riba maka bankbank yang beroperasi sesuai dengan syariah harus menerapkan sistem bagi hasil. Maka dari itu produk yang dimiliki lembaga keuangan syariah tidak menggunakan sistem bunga melainkan menggunakan sistem bagi hasil. Larangan akan riba juga sesuai dengan firman Allah pada An-Nisa ayat 161 (Departemen Agama Rl:2005) :

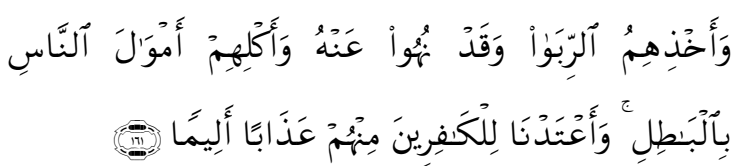
Wa-'akhdhihimu r-ribā wa-qad nuhū 'anhu wa-'aklihim 'amwāla n-nāsi bi-l-bāțtili wa'a 'tadnā li-I-kāfirīna minhum 'adhāban 'alima(na).

Artinya : Dan disebabkan mereka memakan riba, Padahal Sesungguhnya mereka telah dilarang daripadanya, dan karena mereka memakan harta benda orang dengan jalan yang batil. Kami telah 
menyediakan untuk orang-orang yang kafir di antara mereka itu siksa yang pedih.

Dan yang keempat, menurut pendapat Saeed dalam Abuznaid (2012) dalam pendekatan Islam proses produksi akan sebuah produk harus memiliki pedoman dan kriteria bahwasannya produk tersebut harus memiliki nilai dan bermanfaat bagi seluruh masyarakat. Hal ini bertujuan untuk memberikan produk beserta nilai guna yang terbaik sesuai dengan kebutuhan konsumen. Hal ini dimaksudkan untuk menarik minat konsumen dalam membeli maupun menggunakanya.

\section{Harga}

Harga menurut Kotler dan Amstrong (2001:439) adalah sejumlah uang yang dibebankan atas suatu produk dan jasa. Lebih luas lagi, harga adalah sejumlah dari seluruh nilai yang ditukar konsumen manfaat-manfaat memiliki atau menggunakan produk atau jasa tersebut. Dalam Islam dilarang tindakan manipulasi dan menetapkan harga seenaknya sendiri. Tetapi ada pengecualiaan dimana melakukan kontrol harga diperbolehkan asalkan dengan maksud untuk memenuhi kebutuhan pasar akibat terjadinya kelangkaan pasokan sumber daya alam dan tidak merugikan siapapun.

Dalam melakukan kontrol harga itupun menurut Kartajaya dan Sula (2006:178) perusahaan haruslah mengutamakan nilai keadilan. Jika kualitas produk bagus, harganya tentu bisa tinggi. Sebaliknya, jika seseorang telah mengetahui keburukan yang ada di balik produk yang ditawarkan, harganya pun harus disesuaikan dengan kondisi produk tersebut. Sedangkan menurut Suhendi (2010:84) syarat harga pasar yang berlaku di tengah-tengah masyarakat ialah harga yang disepakati kedua belah pihak harus jelas jumlahnya, dapat diserahkan pada saat waktu akad (transaksi). Pengukuran yang jelas dan transparan merupakan suatu hal yang penting, karena prinsip-prinsip syariah mengajarkan mengenai keadilan dan kejujuran apalagi dalam kebijakan kontrol harga (Kartajaya dan Sula, 2006:194).

\section{Tempat}

Tempat/saluran distribusi menurut Lupiyoadi (2013:96) merupakan gabungan antara lokasi dan keputusan atas saluran distribusi, dalam hal ini berhubungan dengan bagaimana cara penyampaian jasa kepada konsumen dan di mana lokasi yang strategis. Arham dalam Abuznaid (2012) berpendapat bahwa tempat/saluran distribusi bagi konsumen harus bisa diakses semudah mungkin. Maka dari itu tugas bagi seorang produsen untuk menentukan tempat/saluran distribusi yang mudah dijangkau dan memberikan kenyamanan bagi konsumen.

Lebih jelasnya Kasmir (2007:56) mengemukakan bahwa pemilihan lokasi perlu dipertimbangkan hal-hal sebagai berikut: 1) Dekat dengan kawasan industri dan pabrik, 2) Dekat dengan lokasi perkantoran, 3) Dekat dengan lokasi 
keramaian atau pasar, 4) Dekat dengan pusat pemerintahan, 5) Dekat dengan lokasi perumahan atau masyarakat, 6) Mempertimbangkan jumlah pesaing yang ada di suatu lokasi, dan 7) Sarana dan prasarana (jalan, pelabuhan, listrik, dan lain-lain). Pendapat yang berebeda diungkapkan berdasarkan sudut pandang Islam dimana menurut Yusanto dan Widjajakusuma (2002:96) tempat usaha harus baik, sehat, bersih dan nyaman. Harus juga dihindarkan melengkapi tempat usaha itu dengan hal-hal yang diharamkan (misalnya gambar porno, minuman keras, dan sebagainya) untuk sekadar menarik pembeli.

\section{Promosi}

Promosi menurut Tjiptono

(1997:219) promosi adalah suatu bentuk komunikasi pemasaran. Komunikasi pemasaran adalah aktivitas pemasaran yang berusaha menyebarkan informasi, mempengaruhi/membujuk, dan mengingatkan pasar sasaran atas perusahaan dan produknya agar bersedia menerima, membeli, loyal pada produk yang ditawarkan perusahaan yang bersangkutan.

Hal yang perlu diperhatikan dalam promosi adalah pemilihan bauran promosi (promotion mix), dimana menurut Sumarni (2003: 297-300) terdiri atas:

1. periklanan (Advertising) lewat media cetak seperti majalah, surat kabar, brosur, edaran, spanduk, papan reklame, maupun dimuat dalam media elektronika seperti radio, film,
2. Promosi Penjualan (Sales Promotion) misalnya pameran, demonstrasi, peragaan

3. Publisitas

4. Penjualan Pribadi (Personal Selling) Terkait dengan promosi dalam Islam , adanya larangan sumpah atas nama Allah dalam rangka untuk mempromosikan produk dan membujuk pembeli untuk membeli barang bukan hanya tidak diperbolehkan tapi akan dicabut berkah allah SWT sesuai sabda Rasulullah SAW (Madani, $2011: 186)$ :

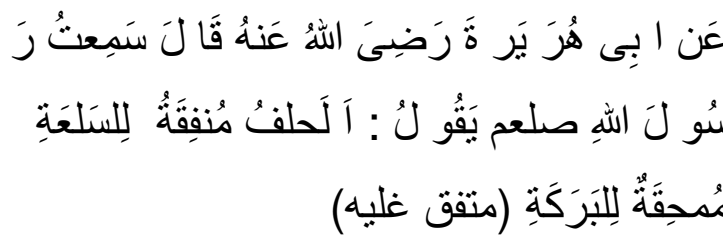

Anbiihuro yartarodikallahu 'anhukoola sami tu rosulullahi salamu yakoolu.

Artinya: "Dari Abu Hurairah Radhiyallahu Anhu, katanya: Aku pernah mendengar Rasulullah SAW bersabda: 'Pengambilan sumpah ketika menjual barang-barang makanan itu akan mendatangkan keuntungan, tapi itu akan menghapuskan keberkatan." (HR Bukhari-Muslim).

\section{Sumber Daya Insani}

Sumber daya insani (SDI) menurut Lupiyoadi (2009:70) sumber daya insani, dalam hal ini adalah tenaga kerja yang dimiliki suatu perusahaan yang sering disebut karyawan, karyawan sangat berperan penting dalam perusahaan jasa karena telibat langsung menyampaikan produk kepelanggan. Dalam Islam sumber daya memiliki beberapa kriteria yang selayaknya ditanamkan dalam diri mereka 
yaitu: pertama, dalam melakukan setiap kegiatannya harus selalu memegang teguh prinsip jujur dan tidak boleh curang. Kejujuran tidak hanya akan membawa kesuksesan bagi usaha yang dijalankan seorang pedagang tetapi juga menjadikan dirinya bagian dari Rasulullah dan para syuhada seperti sabda Rasulullah SAW sebagai berikut (Madani, 2011:177)

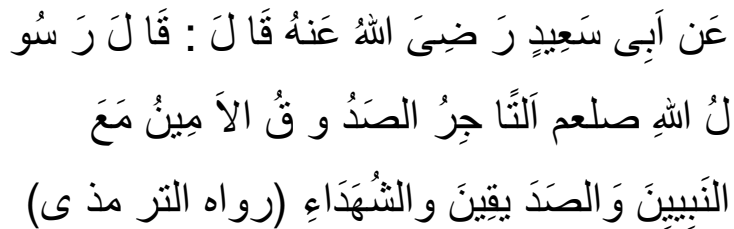

An-abi sa iidin radikallahu 'anhu kola: kola rasulullahi salamu attajiru sodukul amiinu maanabiiyina wasodaakiini syuhada .

"Dari Abu Sa`id Radhiyallahu Anhu, katanya: Rasulullah SAW bersabda: Pedagang yang jujur yang dapat dipercaya itu bersama para Nabi dan orang-orang yang benar serta para syuhada". (HR Tirmidzi).

Kedua, sikap profesional dalam bekerja menjadi pedoman syariah marketer dalam setiap pekerjaan atau tindakan yang dia lakukan. Muhammad pernah mengingatkan, jika menempatkan seseorang bukan pada pekerjaan yang dia kuasai, bersiaplah untuk mengalami kehancuran (Gunara dan Sudibyo, 2007:93). Maka dari itu alangkah pentingnya kemampuan seoarang pemasar dalam menguasai setiap tugas yang diamanahkan kepadanya. Ketiga, Menurut Gunara dan Sudibyo (2007:94) Muhammad SAW sudah menekankan pada pentingnya silahturahmi dalam rangka mengetahui costumer insight dengan menggunakan silahturahmi sebagai salah satu seni dalam berdagang yang tentu saja secara tidak langsung akan menaikkan omzet perdagangan.

\section{Proses}

Proses menurut Arief (2005:99) merupakan gabungan semua aktivitas, umumnya terdiri dari prosedur, jadwal pekerjaan, mekanisme, aktivitas, dan halhal rutin dimana jasa dihasilkan dan disampaikan kepada konsumen. Dalam bauran pemasaran Islam proses ini lebih ditekankan kepada akad yang dilaksanakan pada saat transaksi antara penjual dan pembeli atau antara produsen dan konsumen.

Pengertian akad sendiri dalam Islam menurut Suhendi (2010:46) merupakan suatu perbuatan yang sengaja dibuat oleh dua orang atau lebih berdasarkan keridhaan masing-masing. Adapun syarat yang menyertai akad menurut figh muamalah ialah adanya orang yang berakad dalam pemasaran jasa ini bisa disebut produsen dan konsumen, ada barang/jasa yang diakadkan dan kepemilikannya harus jelas, maksud dan tujuan akad yang dilakukan harus jelas dan sesuai prinsipprinsip Islam.

Kejujuran dan keterbukaan adalah kunci utama yang dipegang Rasulullah dalam melakukan tahapan unsur proses ini dalam berdagang. Sementara itu menurut Harahap (2011:135) dalam fikih dikenal 
juga beberapa pedoman yang dapat dipakai dalam menentukan halal dan haramnya suatu transaksi salah satunya ialah memudahkan pekerjaan, bukan menyulitkan.

\section{Bukti Fisik}

Menurut Lupiyoadi (2013:120) bukti fisik adalah lingkungan fisik perusahaan tempat jasa diciptakan dan tempat penyedia jasa dan konsumen berinteraksi, ditambah unsur berwujud apa pun yang digunakan untuk mengkomunikasikan atau mendukung peranan jasa itu. Bentuk fisik dari pelayanan/service termasuk semua gambaran nyata dalam pelayanan seperti brosur, blangko/kop surat, kartu bisnis, format laporan, dan perlengkapan (Arief, 2005:102). Bukti fisik menurut Abuznaid (2012) dapat dikelompokkan menjadi tiga kategori yaitu:

\section{Facility Exterior (Fasilitas Eksterior)}

Fasilitas eksterior ini adalah sebuah bukti nyata dari lingkungan fisik keberadaan kantor penyedia jasa yang meliputi desain eksterior dari bangunannya, tempat parkir, dan lingkungan sekitarnya.

\section{Facility Interior (Fasilitas Interior)}

Fasilitas interior adalah bukti fisik nyata yang mendukung keindahan dari dalam bangunan tempat penyedia jasa yang terdiri dari desain interior, peralatan yang digunakan untuk melayani pelanggan secara langsung atau digunakan untuk menjalankan bisnis, signage, tata letak, kualitas udara dan suhu, serta kondisi ruang tunggu atau antri.

3. Other Tangibles( bukti fisik lainnya)

Untuk hal ini biasanya berkaitan dengan kinerja perusahaan misalmya barangbarang seperti kartu nama, brosur/pamflet berkaitan dengan jasa yang ditawarkan untuk diberikan kepada konsumen sebagai tanda pengenal instansi. Penampilan karyawan dimana untuk karyawan wanita dianjurkan untuk menggunakan hijab dan pakaian yang menutupi aurat.

Janji

Janji adalah indikator bauran pemasaran Islam yang merupakan elemen yang murni sesuai dengan syariat Islam. Menurut Gunara dan Sudibyo (2007:112) sebuah janji berhubungan erat dengan kepercayaan. Janji adalah ucapan yang menunjukkan kesanggupan atau kesadaran untuk berbuat sesuatu. Memegang teguh dan menepati janji dalam segala urusan baik urusan dagang yang kecil atau besar juga dilakukan oleh Rasulullah SAW. Menurut Afzalurrahman (1997:19) menyatakan bahwa Nabi Muhammad SAW tidak pernah memberi kesempatan pada para pelanggannya untuk mengeluh, la selalu menepati janji dan mengantarkan barang-barang yang kualitasnya telah disepakati oleh kedua belah pihak tepat pada waktunya. Janji erat hubungannya dengan sifat amanah, dimana orang yang memiliki sifat amanah otomatis akan melakukan segala tugas yang dibebankan kepadanya tanpa 
terkecuali. Berdasarkan pendapat Kartajaya dan Sula (2006:126) konsekuensi amanah adalah mengembalikan baik sedikit ataupun banyak, tidak mengambil lebih banyak daripada yang ia miliki, dan tidak mengurangi hak orang lain, baik itu berupa hasil penjualan, fee, jasa, atau upah buruh. Sedangkan menurut Harahap (2011:120) setiap transaksi harus dilakukan sesuai akad perjanjian yang jelas di awal. Jadi segala bentuk akad dan perjanjian berkaitan dengan pelaksanaan maupun imbal hasil berupa nisbah bagi hasil, bonus ataupun upah akan dilaksanakan sesuai dengan akad/perjanjian yang telah disepakati.

\section{Kesabaran}

Kesabaran menurut kamus alQuran berarti 'menahan' baik dalam pengertian fisik-material ataupun immaterial-nonfisik seperti menahan jiwa dalam menghadapi sesuatu yang diinginkan. Kesabaran menurut Abuznaid (2012) adalah elemen yang penting dalam industri jasa. Kesabaran menurutnya merupakan dasar dari komunikasi yang baik. Dalam kegiatan pemasaran, komunikasi yang baik (efektif dan efisien) merupakan kunci dasar untuk memperolah kesuksesan dalam pemasaran.

Perwujudan komunikasi yang baik tidak hanya melalui tutur kata namun juga bisa diwujudkan melalui perilaku yang membuat konsumen merasa nyaman dan dihargai. Perilaku yang dilandasi sikap sabar misalnya, bersikap rendah hati,sopan, dan ramah dalam melayani adalah hal penting yang harus dijaga dalam menjalankan hubungan antar sesama manusia, bisa juga ditampilkan dalam bentuk kesanggupan dan ketepatan (mujahadah dan itqan), baik ketepatan waktu, janji, pelayanan, pelaporan, mengakui kelemahan dan kekurangan (tidak ditutup-tutupi) yang kemudian diperbaiki secara terus menerus, serta menjauhkan diri dari berbuat bohong dan menipu (Kartajaya dan Sula, 2006:191,123).

Melalui sikap bersahabat dan murah hati akan mencairkan suasana dan akan memberikan ketentraman dalam melakukan pekerjaan sehari-hari. Perintah agar kaum muslim bersifat lembut, sopan santun manakala berbicara dan melayani pelanggan juga terdapat pada surat AlIsra ayat 53 (Departemen Agama Rl:2005):

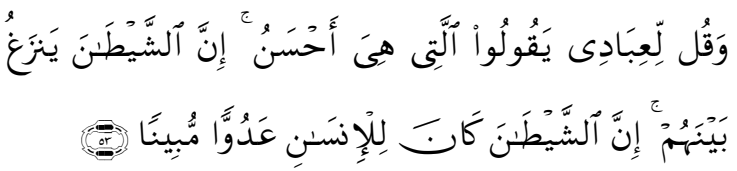
Wakulli-ibaadi yakkulullati hiya-ahsana inna ussyaythona yadzagu baynahum inna ussyaythona kaana lil-inasni aduwwammubiinan.

Artinya: Dan Katakanlah kepada hamhahamba-Ku: "Hendaklah mereka mengucapkan Perkataan yang lebih baik (benar). Sesungguhnya syaitan itu menimbulkan perselisihan di antara mereka. Sesungguhnya syaitan itu adalah musuh yang nyata bagi manusia.

\section{Perilaku Konsumen}

Untuk mendukung keberhasilan dalam proses pemasaran, salah satu 
aspek yang harus diperhatikan adalah perilaku konsumen. Perilaku konsumen menurut Dharmmesta (1997:10) perilaku konsumen (consumer behavior) dapat didefinisikan sebagai kegiatan-kegiatan individu yang secara langsung terlibat dalam mendapatkan dan mempergunakan barang-barang dan jasa-jasa termasuk di dalamnya proses pengambilan keputusan pada persiapan dan penentuan kegiatan-kegiatan tersebut.

Perilaku konsumen antara satu dengan yang lain pastinya berbedabeda. Hal ini dikarenakan adanya perbedaan persepsi di antar mereka. Perbedaan persepsi antara konsumen yang satu dan yang lainnya inilah yang menjadi faktor yang mempengaruhi perilaku konsumen. Menurut Kotler dan Amstrong (2001:196) faktor-faktor itu terdiri dari Kebudayaan, Kelas Sosial, Pribadi, dan Psikologis.

\section{Niat Beli Konsumen}

NiaT beli menurut Imar Khan et al (2013) niat pembelian dapat diidentifikasikan sebagai niat individu untuk membeli sebuah produk secara spesifik yang mereka inginkan, dan produk itu telah mereka pilih setelah memalui tahap evaluasi. Tahap evaluasi inilah adalah tahapan sebelum terjadinya keputusan.

Engel, et al. dalam Chi , Hsin Kuang et al. (2009) membedakan niat pembelian menjadi tiga yaitu :
1. Unplanned buying : konsumen memiliki niat untuk membeli sebuah produk, tetapi semua keputusan pembelian dan memilih jenis dan merek produk di saat sudah ada di toko.

2. Partially planned buying : kondisi dimana konsumen sudah memutuskan jenis produk apa yang akan dibeli, tetapi berkaitan dengan merek diputuskan ketika sudah berada di toko.

3. Fully planned buying : kondisi dimana konsumen sudah menentukan semuanya dari jenis hingga merek produk yang akan dibeli sebelum masuk dalam toko

\section{Hipotesis}

$\mathrm{H1}$ : Bauran pemasaran yang terdiri dari variabel produk, harga, tempat/saluran distribusi, promosi, orang, proses, bukti fisik, janji, dan kesabaran secara simultan berpengaruh signifikan terhadap niat menjadi mitra perspektif Islam pada BMT Beringharjo cabang Madiun.

H2: Bauran pemasaran yang terdiri dari produk, harga, tempat/saluran distribusi, promosi, orang, proses, bukti fisik, janji, dan kesabaran secara parsial berpengaruh signifikan terhadap niat menjadi mitra perspektif Islam pada BMT Beringharjo cabang Madiun.

H3: Variabel proses adalah variabel yang berpengaruh paling dominan terhadap niat menjadi mitra perspektif Islam pada BMT Beringharjo cabang Madiun. 


\section{Model Analisis}

Model analisa yang digunakan dalam penelitian ini yaitu sebagai berikut :

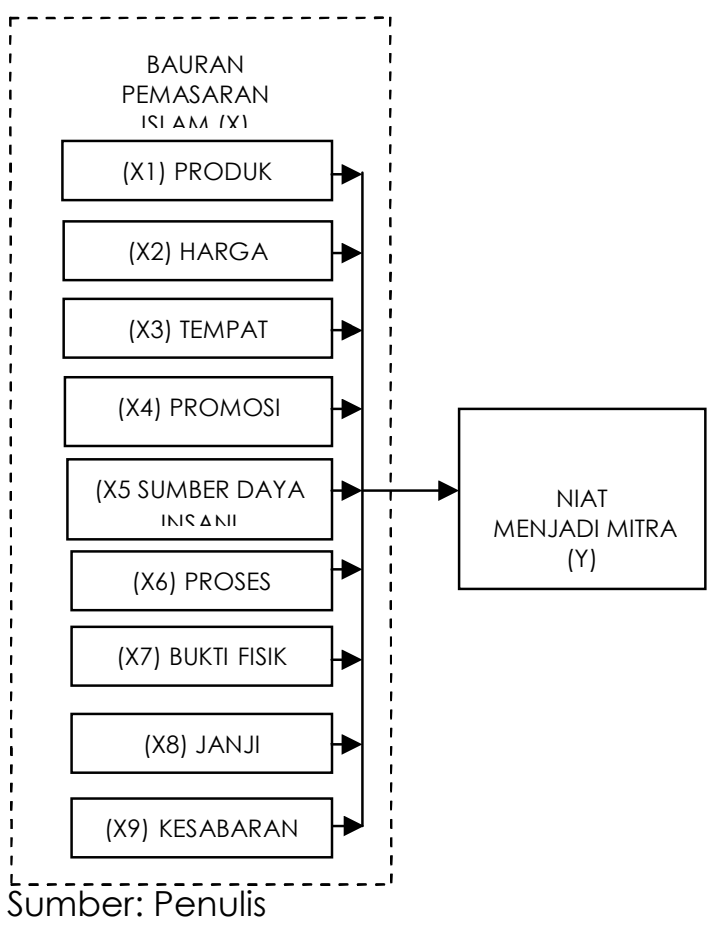

\section{METODE PENELITIAN}

Pendekatan penelitian yang digunakan dalam penelitian ini adalah pendekatan kuantitatif, yaitu penelitian yang menitik beratkan pada pengujian hipotesis. Sugiyono (2010:7) menyatakan bahwa metode kuantitatif dinamakan metode tradisional, karena metode ini sudah cukup lama digunakan sehingga sudah mentradisi sebagai metode untuk penelitian. Penelitian ini utnuk meneliti hubungan pengaruh antara variabel $X$ dan variabel $Y$. Pendekatan ini dimulai dengan teori-teori dan hipotesis, kemudian membuat model analisis, mengidentifikasi variabel, membuat definisi operasional, mengumpulkan data (baik primer maupun sekunder) berdasarkan populasi dan sampel serta melakukan analisis.

\section{Populasi dan Sampel}

Populasi yang digunakan dalam penelitian ini adalah mitra BMT Beringharjo yang aktif melakukan transaksi pada tahun 2014 dan berdomisili di Kota Madiun. Hal ini dimaksudkan untuk mendapatkan penilaian yang mendekati dengan keadaan pemasaran beberapa waktu terakhir ini. Untuk menentukan ukuran sampel dapat digunakan rumus Slovin ( Lolo, 2011 ) sebagai berikut:

$$
\begin{aligned}
& \begin{array}{l}
\mathrm{K} \\
\mathrm{n}
\end{array}=\frac{\mathrm{N}}{1+\mathrm{Ne}^{2}} \\
& \wedge
\end{aligned}
$$
tolerance )

Dari rumus yang digunakan di atas di dapatkan hasil 98,11 dan dibulatkan menjadi 100.

\section{Definisi Operasional}

Produk

Produk adalah produk yang dimiliki BMT Beringharjo berupa pembiayaan dan penghimpunan dana yang ditawarkan kepada mitra. Untuk mengukur variabel harga yang ditawarkan oleh BMT Beringharjo Madiun kepada mitra digunakan indikator-indikator sebagai berikut:

1. Produk BMT Beringharjo Cabang Madiun sudah berprinsip syariah Islam.

2. Informasi berkaitan produk BMT Beringharjo Cabang Madiun jelas dan mudah dimengerti oleh mitra. 
3. Produk-produk BMT Beringharjo Cabang Madiun tidak menggunakan sistem bunga tetapi menggunakan sistem bagi hasil.

4. Variasi produk BMT Beringharjo Cabang Madiun bisa memenuhi kebutuhan mitra.

\section{Harga}

Harga adalah imbal hasil yang dibebankan pada setiap produk BMT Beringharjo. Untuk mengukur variabel harga yang ditawarkan oleh BMT Beringharjo Madiun kepada mitra digunakan indikator-indikator sebagai berikut:

1. Penetapan imbal hasil pada BMT Beringharjo Cabang Madiun dimusyawarahkan dengan mitra.

2. Biaya yang dikeluarkan sesuai dengan manfaaat dan keuntungan yang diperolah mitra.

3. Adanya kejelasan dan keterbukaan dalam pemberian imbal hasil.

4. BMT Beringharjo Cabang Madiun membebankan biaya administrasi yang ringan kepada mitra.

\section{Tempat/Saluran Distribusi}

Tempat adalah lokasi beserta cara penyaluran produk BMT Beringharjo kepada mitra. Untuk mengukur variabel tempat/saluran distribusi pada BMT Beringharjo Madiun kepada mitra digunakan indikator-indikator sebagai berikut:

1. Lokasi BMT Beringharjo Cabang Madiun strategis dan mudah dijangkau.
2. Lokasi BMT Beringharjo Cabang Madiun dekat dengan keramaian dan fasilitas umum.

3. Ruangan kantor BMT Beringharjo Cabang Madiun terasa bersih, nyaman serta terdapat fasilitas yang memadai.

4. Kemanan di lokasi BMT Beringharjo Cabang Madiun baik.

\section{Promosi}

Promosi adalah salah satu cara yang digunakan BMT Beringharjo untuk menginformasikan produk-produk yang mereka miliki kepada mitra. Untuk mengukur variabel promosi BMT Beringharjo Madiun kepada mitra digunakan indikator-indikator sebagai berikut:

1. Promosi dilakukan baik lewat media cetak, elektronik, brosur, pamflet, dan baliho.

2. Promosi yang dilakukan mempermudah mitra untuk mengenal produk-produk dari BMT Beringharjo Cabang Madiun.

3. Cara promosi yang dilakukan membuat mitra tertarik.

4. Metode promosi penjualan langsung memberikan daya tarik bagi mitra.

\section{Sumber Daya Insani (SDI)}

Sumber daya insani adalah karyawan dan staff dari BMT Beringharjo yang telibat langsung menyampaikan dan melayani produk kepada konsumen. Untuk mengukur variabel sumber daya insani pada BMT Beringharjo Madiun kepada mitra digunakan indikatorindikator sebagai berikut: 
1. Karyawan selalu bersikap ramah dalam melayani mitra.

2. Karyawan menguasai segala produk yang dimiliki BMT Beringharjo Cabang Madiun.

3. Karyawan senantiasa bersikap jujur.

4. Silahturahmi antara karyawan dan mitra terjalin dengan baik.

\section{Proses}

Proses adalah serangkaian kegiatan yang dilakukan karyawan dan staff BMT Beringharjo untuk menyuguhkan produk kepada mitra. Untuk mengukur variabel proses pada BMT Beringharjo Madiun kepada mitra digunakan indikator-indikator sebagai berikut:

1. Syarat-syarat menjadi mitra tidak menyulitkan calon mitra.

2. Proses transakasi mudah dan cepat.

3. Akad-akad yang digunakan dalam setiap produknya sesuai syariat Islam.

4. Pelaksanaan transaksi fleksibel bisa langsung di kantor atau dirumah/tempat kerja.

\section{Bukti Fisik}

Bukti fisik adalah tempat beserta sarana dan prasarana yang mendukung serangkaian kegiatan antara karyawan dan staff BMT Beringharjo dengan mitra. Untuk mengukur variabel bukti fisik pada BMT Beringharjo Madiun kepada mitra digunakan indikator-indikator sebagai berikut:

1. Penampilan karyawan sopan dan sesuai syariah Islam (apabila wanita menggunakan hijab dan pakaian yang menutupi aurat).
2. Penempatan papan nama dan logo BMT Beringharjo Cabang Madiun yang jelas dan mudah dikenali.

3. Tampilan eksterior dan interior bangunan BMT Beringharjo Cabang Madiun terlihat indah, dan menarik.

4. BMT Beringharjo menyediakan sejenis brosur, kartu nama dan souvenir untuk mitra sebagai media pengenal instansi.

\section{Janji}

Janji adalah kesediaan dan kesanggupan karyawan dan staff BMT Beringharjo untuk memenuhi segala sesuatu yang telah disampaikan kepada mitra. Untuk mengukur variabel promise pada BMT Beringharjo Madiun kepada mitra digunakan indikator-indikator sebagai berikut:

1. Semua akad yang sudah disepakati dilaksanakan dengan sesuai.

2. Imbal hasil yang diberikan kepada mitra sesuai dengan kesepakatan.

3. Karyawan BMT Beringharjo Cabang Madiun menghargai dan menepati janji yang telah dibuat.

4. Karyawan BMT Beringharjo Cabang Madiun selalu disiplin dan tepat waktu dalam segala urusan.

\section{Kesabaran}

Kesabaran adalah sifat tenang dan selalu siap sedia yang dimiliki karyawan dan staff BMT Beringharjo dalam melayani segala kebutuhan yang diperlukan mitra. Untuk mengukur variabel kesabaran pada BMT Beringharjo Madiun kepada mitra digunakan indikatorindikator sebagai berikut: 
1. Melayani mitra dengan ramah, santun, dan penuh pehatian.

2. Menerima komplain dan saran dari mitra dengan lapang dada.

3. Tidak ragu untuk bertanggung jawab apabila ada kesalahan dari pihak BMT Beringharjo Cabang Madiun.

4. Selalu siap sedia untuk memberikan bantuan kepada mitra.

\section{Niat Menjadi Mitra}

Niat menjadi mitra adalah niat seorang individu atau kelompok untuk menjadi pengguna produk/jasa dari BMT Baringharjo Cabang Madiun. Untuk mengukur variabel niat mitra pada BMT Beringharjo Madiun kepada mitra digunakan indikator-indikator sebagai berikut:

1. Produknya yang sesuai syariah Islam mempengaruhi niat saya menjadi mitra BMT Beringharjo Cabang Madiun.

2. Promosinya yang menarik mempengaruhi niat saya mitra BMT Beringharjo Cabang Madiun.

3. Ajakan teman, tetangga, saudara dan kerabat mempengaruhi niat saya menjadi mitra BMT Beringharjo Cabang Madiun.

4. Prosesnya mudah dan pelayanannya ramah mempengaruhi niat saya mitra BMT Beringharjo Cabang Madiun.

\section{Teknik Analisis}

Teknik analisis data yang digunakan adalah analisis regresi linear berganda. Analisis ini untuk mengetahui hubungan antara variabel eksogen dengan variabel endogen apakah masing-masing variabel eksogen berhubungan positif atau negatif dan untuk memprediksi nilai dari variabel endogen apabila nilai variabel eksogen mengalami kenaikan atau penurunan. Persamaan regresi linear berganda sebagai berikut:

$Y=a+\beta_{1} X_{1}+\beta_{2} X_{2} \beta_{3} X_{3}+\beta_{4} X_{4}+\beta_{5} X_{5}+\beta$

${ }_{6} X_{6}+\beta_{7} X_{7}+\beta_{8} X_{8}+\beta_{9} X_{9}+e$

Keterangan:

$Y=$ Niat menjadi mitra

$\mathrm{X}_{1}=$ Produk

$\mathrm{X}_{2}=$ Harga

$X_{3}=$ Tempat/Saluran distribusi

$\mathrm{X}_{4}=$ Promosi

$X_{5}=$ Sumber daya insani (sdi)

$X_{6}=$ Proses

$\mathrm{X}_{7}=$ Bukti Fisik

$X_{8}=$ Janji

$\mathrm{X}_{9}=$ Kesabaran

$a=$ Konstanta

$\beta_{1}=$ Koefisien regresi variabel produk

$\beta_{2}=$ Koefisien regresi variabel harga

$\beta 3=$ Koefisien regresi variabel tempat/saluran distribusi

$\beta_{4}=$ Koefisien regresi variabel promosi

$\beta_{5}=$ Koefisien regresi variabel sumber daya insani (sdi)

$\beta_{6}=$ Koefisien regresi variabel proses

$\beta_{7}=$ Koefisien regresi variabel bukti fisik

$\beta_{8}=$ Koefisien regresi variabel janji

$\beta_{9}=$ Koefisien regresi variabel kesabaran $e=$ Pengganggu (error) 
IV. HASIL DAN PEMBAHASAN

Analisa Regresi Linier Berganda

Tabel 1

\section{Analisis Regresi Linier Berganda}

\begin{tabular}{|c|c|c|c|}
\hline Variabel & $\begin{array}{c}\text { Koef. } \\
\text { Reg }\end{array}$ & $\begin{array}{c}\dagger \\
\text { hitung }\end{array}$ & $\begin{array}{c}\text { Signifika } \\
\mathrm{n}\end{array}$ \\
\hline $\begin{array}{c}\text { Konstant } \\
\text { a }\end{array}$ & $-0,192$ & $-1,729$ & 0,087 \\
\hline Produk & 0,126 & 4,073 & 0,000 \\
\hline Harga & 0,103 & 3,022 & 0,003 \\
\hline $\begin{array}{l}\text { Tempat/ } \\
\text { Saluran } \\
\text { Distribusi }\end{array}$ & 0,154 & 5,872 & 0,000 \\
\hline Promosi & 0,109 & 5,137 & 0,000 \\
\hline $\begin{array}{l}\text { Sumber } \\
\text { Daya } \\
\text { Insani }\end{array}$ & 0,133 & 4,466 & 0,000 \\
\hline Proses & 0,072 & 2,340 & 0,021 \\
\hline Bukti Fisik & 0,115 & 4,323 & 0,000 \\
\hline Janji & 0,141 & 3,986 & 0,000 \\
\hline $\begin{array}{l}\text { Kesabar } \\
\text { an }\end{array}$ & 0,089 & 2,483 & 0,015 \\
\hline \multicolumn{2}{|c|}{$\begin{array}{c}\text { Koefisien } \\
\text { determinasi }\left(\mathrm{R}^{2}\right)\end{array}$} & \multicolumn{2}{|c|}{0,951} \\
\hline \multicolumn{2}{|c|}{$\begin{array}{l}\text { Koefisien Korelasi } \\
(\mathrm{R})\end{array}$} & \multicolumn{2}{|c|}{0,975} \\
\hline \multicolumn{2}{|c|}{ F Hitung } & \multicolumn{2}{|c|}{195,805} \\
\hline \multicolumn{2}{|c|}{ Sianifikan } & \multicolumn{2}{|c|}{0,000} \\
\hline
\end{tabular}

Sumber: Hasil olah data

\section{Koefisien Determinasi}

Nilai dari koefisien determinasi dari hasil perhitungan adalah 0,951 yang berarti bahwa sebesar 95,1 \% niat menjadi mitra (variabel endogen) dipengaruhi oleh variabel eksogen yang dimasukkan dalam model yaitu bauran pemasaran perspektif Islam yang terdiri dari produk, harga, tempat/saluran distribusi, promosi, sumber daya insani, proses, bukti fisik, janji dan kesabaran. Sedangkan sisanya sebesar 4,9 \% dipengaruhi oleh variabel lain yang tidak dimasukkan dalam model.

\section{Koefisien Korelasi berganda}

Nilai $R$ yang sangat tinggi, yaitu sebesar 0,975 menunjukkan adanya hubungan yang sangat kuat antara semua variabel eksogen produk, harga, tempat/saluran distribusi, promosi, sumber daya insani, proses, bukti fisik, janji dan kesabaran dengan variabel endogen niat menjadi mitra $(Y)$.

\section{Koefisien Regresi}

$$
\begin{aligned}
Y= & 0,192+0,126 X_{1}+0,103 X_{2}+0,154 X_{3}+ \\
& 0,109 X_{4}+0,133 X_{5}+0,072 X_{6}+0,115 X_{7}+ \\
& 0,141 X_{8}+0,089 X_{9}
\end{aligned}
$$

Nilai koefisien regresi variabel $X 1, X 2, X 3$, X4, X5, X6, X7, X8, dan X9 bernilai positif dan tanda positif pada nilai koefisien regresi melambangkan hubungan yang searah antara kesembilan variabel bebas tersebut terhadap variabel terikat yaitu Y, artinya jika nilai dari produk, harga, tempat/saluran distribusi, promosi, sumber daya insani, proses, bukti fisik, janji dan kesabaran semakin baik maka tingkat niat menjadi mitra (Y) juga akan mengalami peningkatan semakin positif.

\section{Uji F (Uji secara bersama)}

Nilai $F$ hasil regresi adalah sebesar 195,805, dengan nilai probabilitas kesalahan (Sig) sebesar 0,000. Nilai signifikansi ini lebih kecil dari 0,05 sehingga ada pengaruh secara bersama - sama variabel pada variabel produk, harga, tempat/saluran distribusi, promosi, sumber daya insani, proses, bukti fisik, janji, dan kesabaran terhadap niat menjadi mitra perspektif Islam pada BMT Beringharjo Cabang Madiun.

\section{Uji T (Uji secara terpisah)}

Tabel 1 menunjukkan bahwa produk (X1), harga (X2), tempat/saluran 
distribusi (X3), promosi (X4), sumber daya insani (X5), proses (X6), bukti fisik (X7), janji (X8), dan kesabaran (X9) masing-masing menghasilkan nilai signifikansi $\dagger$ hitung yang lebih kecil dari 0.05 ( $a=5 \%)$ yaitu 0,000 untuk $X 1,0,003$ untuk $X 2,0,000$ untuk $X 3,0,000$ untuk $X 4,0,000$ untuk $X 5,0,021$ untuk $X 6,0,000$ untuk $X 7,0,000$ untuk $X 8$, 0,015 untuk $\times 9$. Dari hasil ini maka dapat disimpulkan bahwa secara parsial masing-masing variabel tersebut memiliki pengaruh yang signifikan terhadap niat menjdai mitra.

\section{Nilai Beta}

Tabel 2

\section{Perhitungan Nilai Beta}

\begin{tabular}{|c|c|}
\hline Variabel & Beta \\
\hline Produk & 0,142 \\
\hline Harga & 0,112 \\
\hline $\begin{array}{c}\text { Tempat/Saluran } \\
\text { Distribusi }\end{array}$ & 0,183 \\
\hline Promosi & 0,156 \\
\hline $\begin{array}{c}\text { Sumber Daya } \\
\text { Insani }\end{array}$ & 0,164 \\
\hline Proses & 0,094 \\
\hline Bukti Fisik & 0,147 \\
\hline Janji & 0,171 \\
\hline Kesabaran & 0,097 \\
\hline
\end{tabular}

Sumber: Hasil olah data

Hasil pengujian menunjukkan nilai beta untuk variabel tempat/saluran distribusi merupakan variabel yang berpengaruh dominan dengan nilai beta terbesar yaitu 0,183. Ini berarti dari sembilan variabel bauran pemasaran perspektif Islam, variabel tempat/saluran distribusi yang berpengaruh dominan pada niat menjadi mitra perspektif Islam pada BMT Beringharjo Cabang Msdiun.

\section{Pengujian Normalitas}

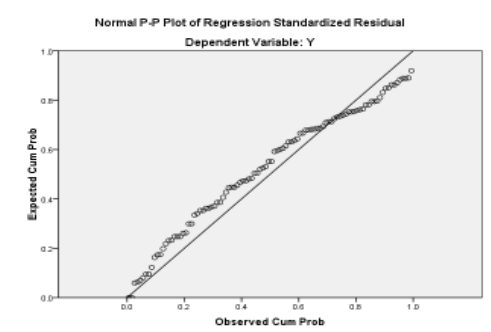

Sumber: Hasil olah data

Grafik P-Plot menggambarkan bahwa data menyebar di sekitar garis diagonal dan mengikuti arah garis diagonal menunjukkan pola distribusi normal maka model regresi memenuhi asumsi normalitas.

Pengujian Gejala Multikolinearitas

Tabel 3

Hasil Uji Multikolinearitas

\begin{tabular}{|c|c|c|}
\hline Variabel & $\begin{array}{c}\text { Nilai } \\
\text { VIF }\end{array}$ & Keterangan \\
\hline Produk & 2,240 & $\begin{array}{c}\text { Tidak terjadi } \\
\text { multikolinieritas }\end{array}$ \\
\hline Harga & 2,559 & $\begin{array}{c}\text { Tidak terjadi } \\
\text { multikolinieritas }\end{array}$ \\
\hline $\begin{array}{c}\text { Tempat/Saluran } \\
\text { Distribusi }\end{array}$ & 1,791 & $\begin{array}{c}\text { Tidak terjadi } \\
\text { multikolinieritas }\end{array}$ \\
\hline Promosi & 1,711 & $\begin{array}{c}\text { Tidak terjadi } \\
\text { multikolinieritas }\end{array}$ \\
\hline $\begin{array}{c}\text { Sumber Daya } \\
\text { Insani }\end{array}$ & 2,512 & $\begin{array}{c}\text { Tidak terjadi } \\
\text { multikolinieritas }\end{array}$ \\
\hline Proses & 2,978 & $\begin{array}{c}\text { Tidak terjadi } \\
\text { multikolinieritas }\end{array}$ \\
\hline Bukti Fisik & 2,135 & $\begin{array}{c}\text { Tidak terjadi } \\
\text { multikolinieritas }\end{array}$ \\
\hline Janji & 3,409 & $\begin{array}{c}\text { Tidak terjadi } \\
\text { multikolinieritas }\end{array}$ \\
\hline Kesabaran & 2,826 & $\begin{array}{c}\text { Tidak terjadi } \\
\text { multikolinieritas }\end{array}$ \\
\hline
\end{tabular}

Sumber: Hasil olah data

Berdasarkan tabel diatas diketahui bahwa semua variabel eksogen mempunyai nilai VIF $<10$. Hal ini dapat disimpulkan bahwa pada model regresi tidak terjadi Multikolinearitas. 
Pengujian Gejala Heteroskedastisitas

Tabel 4

Hasil Uji Heterokedastisitas

\begin{tabular}{|c|c|c|c|}
\hline Variabel & $\begin{array}{l}\text { Koef. } \\
\text { Rank } \\
\text { Spea } \\
\text { rman }\end{array}$ & $\begin{array}{c}\text { Signifik } \\
\text { ansi }\end{array}$ & $\begin{array}{c}\text { Keterang } \\
\text { an }\end{array}$ \\
\hline Produk & 0,049 & 0,630 & $\begin{array}{c}\text { Homoske } \\
\text { dastis }\end{array}$ \\
\hline Harga & 0,050 & 0,624 & $\begin{array}{c}\text { Homoske } \\
\text { dastis }\end{array}$ \\
\hline $\begin{array}{c}\text { Tempat/Sal } \\
\text { uran } \\
\text { Distribusi }\end{array}$ & $0,-$ & 0,654 & $\begin{array}{c}\text { Homoske } \\
\text { dastis }\end{array}$ \\
\hline Promosi & 0,116 & 0,250 & $\begin{array}{c}\text { Homoske } \\
\text { dastis }\end{array}$ \\
\hline $\begin{array}{c}\text { Sumber } \\
\text { Daya Insani }\end{array}$ & $\begin{array}{c}- \\
0,063 \\
\end{array}$ & 0,537 & $\begin{array}{c}\text { Homoske } \\
\text { dastis }\end{array}$ \\
\hline Proses & 0,011 & 0,914 & $\begin{array}{c}\text { Homoske } \\
\text { dastis }\end{array}$ \\
\hline Bukti Fisik & 0,010 & 0,920 & $\begin{array}{c}\text { Homoske } \\
\text { dastis }\end{array}$ \\
\hline Janji & $\begin{array}{c}- \\
0,030\end{array}$ & 0,975 & $\begin{array}{c}\text { Homoske } \\
\text { dastis }\end{array}$ \\
\hline Kesabaran & 0,019 & 0,853 & $\begin{array}{c}\text { Homoske } \\
\text { dastis }\end{array}$ \\
\hline
\end{tabular}

Sumber: Hasil olah data

Dari tabel 4 diatas dapat dilihat bahwa nilai signifikasi untuk semua variabel lebih besar dari 0,05 dengan demikian dapat disimpulkan bahwa terjadi gejala homoskedastis atau tidak terjadi hubungan antara variabel pengganggu dengan variabel eksogen, sehingga variabel endogen benar-benar hanya dijelaskan oleh variabel eksogen.

\section{SIMPULAN DAN SARAN}

\section{Simpulan}

Berdasarkan hasil pengolahan data dalam penelitian ini, dapat ditarik simpulan sebagai berikut:

1. Variabel bauran pemasaran yang terdiri dari produk, harga, tempat/saluran distribusi, promosi, sumber daya insani, proses, bukti fisik, janji dan kesabaran berpengaruh signifikan secara simultan terhadap niat menjadi mitra perspektif Islam pada BMT Beringharjo cabang Madiun.

2. Variabel bauran pemasaran yang terdiri dari produk, harga, tempat/saluran distribusi, promosi, sumber daya insani, proses, bukti fisik, janji dan kesabaran berpengaruh signifikan secara parsial terhadap niat menjadi mitra pada BMT Beringharjo cabang Madiun.

3. Variabel tempat/saluran distribusi merupakan variabel yang berpengaruh dominan terhadap niat menjadi mitra dengan nilai Beta sebesar 0,183. Pengaruh dominan tersebut menunjukkan bahwa variabel tempat/saluran distribusi merupakan aspek yang menjadi alasan utama bagi mitra mengambil niat untuk menjdai mitra pada BMT Beringharjo.

\section{Saran}

Dari hasil penelitian mengenai pengaruh bauran pemasaran perspektif Islam yang terdiri dari produk, harga, tempat/saluran distribusi, promosi, sumber daya insani, proses, bukti fisik, janji dan kesabaran, semuanya berpengaruh positif terhadap niat menjadi mitra. Saran yang akan diberikan oleh penulis didasarkan pada nilai indikator variabel eksogen yang paling rendah. Maka dari serangkaian penelitian yang dilakukan mengahsilkan saran sebagai berikut :

1. Mitra BMT Beringharjo cabang Madiun beranggapan bahwa promosi baik 
melalui media cetak, elektronik, brosur, pamflet, dan baliho yang dilakukan BMT Beringharjo masih kurang. Hendaknya pihak BMT Beringharjo cabang Madiun mempertimbangkan hal ini agar mulai meningkatkan kegiatan promosi mereka. Hal ini dimaksudkan agar aktivitas promosi lebih beragam sehingga bisa menarik perhatian dan sekaligus mengakrabkan BMT kepada calon mitra ataupun mitra yang sudah bergabung.

2. Mitra BMT Beringharjo cabang Madiun beranggapan bahwa promosi yang sudah dilakukan BMT Beringharjo cabang Madiun masih kurang membantu mitra untuk mengenali produk-produk dari BMT Beringharjo Cabang Madiun. Kondisi ini menunjukkan bahwa pihak BMT Beringharjo cabang Madiun harus bekerja lebih keras lagi untuk mensosialisasikan produk-produk mereka dan perbedaannya dengan produk yang ada pada lembaga keuangan lainnya terutama dengan lembaga keuangan konvensional melalui kegiatan promosi mereka.

3. Mitra BMT Beringharjo cabang Madiun beranggapan bahwa metode promosi penjualan langsung belum begitu menarik bagi mereka. Padahal ini adalah cara promosi yang diandalkan pihak BMT Beringharjo cabang Madiun. Melihat hal ini berarti pihak BMT Beringharjo harus mulai membuat cara promosi penjualan langsung yang lebih menarik dan kreatif lagi. Bisa dengan menambahkan tools dalam melakukan promosi seperti brosur, kartu nama atau stiker sebagai souvenir untuk masyarakat yang sudah diberikan sosialialisasi, atau dengan membuat event-event yang menyertai kegiatan penjualan langsung agar lebih menarik.

\section{DAFTAR PUSTAKA}

Abuznaid, Samir. "Islamic Marketing: Addressing The Muslim Market". AnNajah Univ. J. Res. (Humanities). Vol. 26(6), 2012.

Afzalurrahman. 1997. Muhammad sebagai Seorang Pedagang. Jakarta: Yayasan Swarna Bhumy.

Arief, Muhtosim. 2005. Pemasaran\&Jasa Kualitas Pelayanan. Malang: Bayumedia Publishing.

Chi , Hsin Kuang et al. 2009. The Impact of Brand Awareness on Consumer Purchase Intention: The Mediating Effect of Perceived Quality and BrandLoyalty. The Journal of International Management Studies, Volume 4, Number 1, February, 2009.

Departemen Agama RI. 2005. Al-Quran \& Terjemahan. Bandung: $\mathrm{cV}$ Penerbit Diponegoro.

Dharmmesta, Basu Swasta dan T. Hani Handoko. 1997. Manajemen Pemasaran Jasa. Yogyakarta: BPFEYOGYAKARTA.

Gunara, Thorik dan Utus Hardiono Sudibyo. 2007. Marketing Muhammad SAW. Bandung: PT Karya Kita. 
Harahap, Sofyan S. 2011 . Etika Bisnis dalam Perspektif Islam. Jakarta: Salemba Empat.

Hurriyati, Ratih. 2010. Bauran Pemasaran dan Loyalitas Konsumen. Bandung: ALFABETA CV.

http://bisniskeuangan.kompas.com/read/ 2013/1 1/25/1255414/Perkembangan.K evangan.Syariah.Menggembirakan (diakses 20 Juni 2014 pukul 19:51 WIB).

http://www.setkab.go.id/berita-11096-

jangan-pandang-entengpertumbuhan-ekonomi-syariah-diindonesia.html (diaksesl 4 Maret 2014).

Kartajaya, Hermawan \& Muhammad Syakir Sula. 2006. Syariah Marketing. Jakarta: Mizan.

Kasmir. 2007. Studi Kelayakan Bisnis. Jakarta: PT. Raja Grafindo Persada. Khan, Imar et al. 2013. Impact of Brand Related Attributes on Purchase Intention of Costumers. Interdisciplinary Journal of Contemporary Research in Business. Vol 4, No 3.

Kotler, Philir dan Gary Armstrong. 2001. Prinsip-Prinsip Pemasaran. Jakarta: Penerbit Airlangga.

Kartajaya, Hermawan \& Muhammad Syakir Sula. 2006. Syariah Marketing. Jakarta: Mizan.

Lolo, Irwinda N. T Andi. 2011. Pengaruh Strategi Marketing Mix Terhadap Keputusan Konsumen Yang Menabung Pada PT. Bank Mandiri (Persero) TBK, Cabang Makasar
Kartini. Tugas akhir diterbitkan Universitas Hasanudin Makasar.

Lupiyoadi, Rambat. 2009. Manajemen Pemasaran Jasa. Jakarta: Salemba Empat.

\section{---------, 2013. Manajemen \\ Pemasaran Jasa. Jakarta: Salemba Empat.}

Madani, Dr. 2011. Ayat-Ayat dan Hadis Ekonomi Syariah. Jakarta: PT Rajagrafindo Persada.

Nafik, Muhammad. 2009. Bursa Efek \& Investasi Syariah. Jakarta: PT Serambi Ilmu Semesta.

Sugiyono. 2012. Metode Penelitian Kuantitatif Kualitatif Dan R\&D. Bandung : Alfabeta.

Suhendi, Hendi. 2010. Fiqh Muamalah. Jakarta: PT. Raja Grafindo Persada.

Sumarni, Murti. 2003. Pengantar Bisnis (Dasar-Dasar Ekonomi Perusahaan). Yogyakarta: Liberty Yogyakarta Tjiptono, Fandy. 1997. Strategi Pemasaran. Yogyakarta: ANDI.

Yusanto, Muhammad Ismail dan Muhammad Karebet Widjajakusuma. 2002. Menggagas Harahap, Sofyan S. 2011. Etika Bisnis dalam Perspektif Islam. Jakarta: Salemba Empat. 